\begin{tabular}{|l|l|l|l|l|l|}
\hline J. Tek. Ling & Vol. 12 & No. 3 & Hal. 233 - 240 & Jakarta, September 2011 & ISSN 1441-318X \\
\hline
\end{tabular}

\title{
KUALITAS KOMPOS SAMPAH RUMAH TANGGA YANG DIBUAT DENGAN MENGGUNAKAN "KOMPOSTER" AEROBIK
}

\author{
Firman L. Sahwan'), Sri Wahyono ${ }^{1)}$ dan Feddy Suryanto ${ }^{2)}$ \\ ${ }^{1)}$ Peneliti di Pusat Teknologi Lingkungan \\ 2)Perekayasa di Pusat Teknologi Lingkungan \\ Badan Pengkajian dan Penerapan Teknologi \\ BPPT Gedung II It 20, Jln. MH Thamrin no. 8 Jakarta 10340
}

\begin{abstract}
Abstrak
Upaya pembuatan kompos sampah rumah tangga dengan menggunakan "komposter", dapat membantu upaya pengelolaan sampah kota dalam bentuk: mengurangi jumlah timbulan sampah di sumber, mengurangi biaya transportasi pengangkutan sampah dan dapat memperpanjang umur TPA. Untuk itulah penelitian ini dilakukan dengan tujuan mengevaluasi efektivitas proses pengomposannya, sekaligus mengetahui kualitas kompos yang dihasilkan. Parameter analisis kualitas kompos yang digunakan adalah: keberadaan mikroba kontaminan, tingkat kematangan, serta kesesuaian dengan Permentan No. 28 of 2009 atau SNI Kompos 2004. Hasil penelitian menyimpulkan bahwa proses pengomposannya berjalan dengan baik dan cukup efektif, serta menggambarkan proses dekomposisi secara aerobik. Adapun produk kompos yang dihasilkan berkualitas baik, bebas dari mikroba kontaminan (patogen), memenuhi persyaratan kompos matang dan secara umum sesuai dengan parameter yang dipersyaratkan oleh Permentan Pupuk Organik atau SNI Kompos 2004.
\end{abstract}

kata kunci : limbah padat, komposter, pengomposan, skala rumah tangga, kualitas kompos

\begin{abstract}
Organic waste composting using individual composter will have positive impact on the municipal solid waste management due to it can: significantly reduce the amount of waste production in the source, reduce cost of transportation, and extend the life span of the landfill. The aim of this research is to evaluate the effectiveness of householdscale composting process, as well as the compost product quality. Parameters of compost quality are the existence of pathogenic microbes, maturity, and conformity with compost regulation. The research concluded that the composting process proceeds effectively and the process of decomposition of organic matter is in the aerobic condition. The quality of compost are free from pathogenic microbes, mature compost and generally meet the parameters required by Permentan No. 28 of 2009 or by SNI of compost 2004.
\end{abstract}

key words : Municipal solid waste, composter, household-scale composting, compost quality 


\section{PENDAHULUAN}

\subsection{Latar Belakang}

Yang dimaksud dengan sampah adalah sisa kegiatan sehari-hari manusia dan/ atau proses alam yang berbentuk padat ${ }^{1}$. Sedangkan sampah rumah tangga adalah sampah yang berasal dari kegiatan seharihari dalam rumah tangga, tidak termasuk tinja dan sampah spesifik ${ }^{1)}$. Sampah rumah tangga merupakan sampah yang paling dominan, dilihat dari jumlah yang dihasilkan setiap harinya. Sebagai gambaran, di Propinsi DKI Jakarta menghasilkan sampah rumah tangga sebesar 1,36 liter atau 0,34 $\mathrm{kg}$ per orang per hari, dari total timbulan sampah yang 2,97 liter atau 0,64 $\mathrm{kg}$ per orang per hari²).

Kalau pada tahun 2010 penduduk Indonesia mencapai 237.556.363 jiwa3), dan diasumsikan jumlah timbulan sampah sebesar 2,97 liter per orang per hari²), maka per harinya di seluruh Indonesia akan dihasilkan timbulan sampah sebesar $705.542 \mathrm{~m}^{3}$. Dengan jumlah timbulan sampah yang begitu besar, tingkat pelayanan yang rendah, yaitu hanya mencapai $56 \% 4$ ) dan pengelolaan yang kurang baik1), maka permasalahan-permasalahan yang berkaitan dengan persampahan akan dengan mudah bermunculan.

Untuk itulah Undang-Undang Nomor 18 Tahun 2008, tentang Pengelolaan Sampah ditetapkan dengan tujuan untuk meningkatkan kesehatan masyarakat dan kualitas lingkungan serta menjadikan sampah sebagai sumberdaya ${ }^{1)}$. Jiwa dari UU tersebut adalah pengurangan dan penanganan sampah.

Yang dimaksud dengan pengurangan sampah meliputi kegiatan pembatasan timbulan sampah, pendauran ulang sampah dan pemanfaatan kembali sampah. Kegiatan pendauran ulang sampah dalam rangka menjadikan sampah sebagai sumberdaya, berkaitan erat dengan komposisi sampah di Indonesia yang sekitar $71 \%$ merupakan sampah yang dapat dijadikan kompos ${ }^{4}$. Melihat karakter sampah organik yang tinggi kadar airnya $(59,88 \%)^{2)}, \mathrm{C} / \mathrm{N}$ ratio sebesar $37,1^{5}$ ) dan rentang ukuran sekitar 2,5-7,5 Cm, merupakan karakter atau nilai yang cocok untuk proses komposting ${ }^{6-10)}$. Hasil kajian pembuatan kompos sampah kota skala kawasan dengan menggunakan metoda open windrow yang dilakukan di Sleman, Yogyakarta ${ }^{11)}$, Rawasari, Jakarta ${ }^{12)}$ dan Buleleng, Bali ${ }^{13)}$ menyimpulkan bahwa proses kompostingnya berjalan baik dengan kualitas kompos yang dihasilkan memenuhi SNI Kompos Sampah ${ }^{14}$ dan Permentan Pupuk Organik ${ }^{15)}$.

Sedangkan kegiatan penanganan sampah merupakan rangkaian kegiatan mulai dari pemilahan, pengumpulan, pengangkutan, pengolahan dan pemrosesan akhir sampah ${ }^{1)}$. Dari kegiatan penanganan sampah tersebut, terdapat 3 (tiga) lokasi penanganan yaitu: tempat sumber sampah (salah satunya rumah tangga), tempat penampungan sementara atau tempat pengolahan sampah terpadu dan tempat pemrosesan akhir. Kalau dikaitkan dengan lokasi TPA yang umumnya jauh dari sumber sampah, sehingga biaya pengangkutan sampah menjadi mahal, maka upaya daur ulang sampah yang dilakukan di lokasi yang semakin dekat dengan sumber sampah menjadi semakin baik. Dengan demikian upaya daur ulang sampah rumah tangga menjadi kompos menjadi sangat tepat untuk dilakukan.

Upaya pembuatan kompos sampah rumah tangga dengan menggunakan "komposter", dapat membantu upaya pengelolaan sampah kota dalam bentuk: mengurangi jumlah timbulan sampah di sumber, mengurangi biaya transportasi pengangkutan sampah, dan memperpanjang umur TPA.

\subsection{Kendala Komposting Skala Rumah Tangga}

Proses dekomposisi limbah oleh mikroba akan menghasilkan energi dalam 
bentuk panas. Panas ini, sebagian akan tersimpan dalam tumpukan bahan yang dikomposkan (proses insulasi) dan sebagian lagi akan keluar melalui proses penguapan atau melalui aerasi. Panas yang dihasilkan cukup tinggi, yaitu mencapai $60-75^{\circ} \mathrm{C}$ pada saat proses pengomposan berlangsung ${ }^{11,12}$ dan 13). Panas yang tinggi tersebut menjadi parameter utama yang menggambarkan bahwa proses komposting berjalan dengan baik. Manfaat dari panas yang tinggi adalah mematikan bakteri patogen dan bibit gulma selain mempercepat proses pengomposan itu sendiri.

Untuk dapat menghasilkan panas yang tinggi, dibutuhkan sejumlah materi yang cukup, sehingga terjadi proses insulasi. Permasalahannya adalah volume "komposter" yang digunakan untuk membuat kompos dari sampah rumah tangga hanya 60 liter. Volume tersebut tidak cukup untuk membuat terjadinya proses insulasi yang sempurna. Dengan menggunakan "komposter" yang lebih besar (volume 160 liter), suhu paling tinggi yang bisa dicapai sekitar $50-55{ }^{\circ} \mathrm{C}$ dan terjadi paling lama sekitar 10 (sepuluh) hari5).

\subsection{Tujuan Penelitian}

Tujuan penelitian ini adalah untuk mengetahui kualitas kompos sampah rumah tangga yang dibuat dengan menggunakan komposter swkala rumah tangga kapasitas 6 liter.

\section{METODOLOGI}

\subsection{Tempat dan Waktu Penelitian}

Penelitian dilakukan di empat lokasi kompleks permukiman, yaitu: Rawajati, Jakarta Selatan; Puspiptek, Serpong; serta Kuala Kencana dan Tembagapura, Papua.

Rentang waktu penelitian pembuatan "komposter" dan komposnya dilakukan pada tahun 2010-2011. Sedangkan pengambilan sampel komposnya, dilakukan pada bulan
Pebruari-Maret 2011. Analisa laboratorium dilakukan di Laboratorium Balai Penelitian Tanah Bogor.

\subsection{Proses Pembuatan Kompos}

"Komposter" yang digunakan merupakan "komposter" aerobik rancangan dari Pusat Teknologi Lingkungan, BPPT, yang dibuat dengan menggunakan bahan: tong plastik 60 liter, styrofoam bekas, net/ jaring, karpet dan kompos.

Sedangkan pembuatan komposnya dilakukan dengan sistem aerobik terkendali, dengan tahapan sebagai berikut:

Tahap 1. Sampah organik yang baik untuk dikomposkan, setelah dipisahkan dari sampah yang lain, dipotong-potong kecil sehingga berukuran $0,5-1 \mathrm{Cm}$.

Tahap 2. Memasukkan sampah ke dalam "komposter" yang telah berisi $3 \mathrm{~kg}$ kompos yang berfungsi sebagai starter sekaligus conditioner. Sampah diaduk merata dengan kompos, kemudian diselimuti dengan karpet dan ditutup.

Tahap 3. Pada hari berikutnya dilakukan hal yang sama dengan tahap 1 dan tahap 2 sampai komposter penuh. Setelah penuh, proses pengadukan diusahakan tetap dilakukan setiap minggu sekali.

\subsection{Parameter Analisis}

Parameter untuk menganalisis kualitas kompos adalah: keberadaan mikroba kontaminan (E. coli dan Salmonella $\mathrm{sp}^{14 \mathrm{dan} 15)}$; tingkat kematangan (rasio $\mathrm{C} / \mathrm{N}, \mathrm{N}-\mathrm{NH}_{4} / \mathrm{N}$ total dan $\mathrm{N}-\mathrm{NO}_{3} / \mathrm{N}-\mathrm{NH}_{4}$ ) serta kesesuaian dengan Permentan Pupuk Organik ${ }^{15)}$ atau SNI Kompos ${ }^{14)}$

\section{HASIL DAN PEMBAHASAN}

Hasil analisa laboratorium produk kompos dari ke empat lokasi penelitian, yang menggambarkan kualitas kompos tersebut, disajikan pada Tabel 1. Berdasarkan data pada Tabel 1 tersebut, secara umum 
dapat disimpulkan bahwa produk kompos yang dihasilkan berkualitas baik. Untuk

pembahasan yang lebih mendalam, akan disampaikan pada subbab berikut :

Tabel 1. Kualitas Produk Kompos Hasil Penelitian

\begin{tabular}{|c|c|c|c|c|c|c|c|c|}
\hline \multirow[b]{2}{*}{ NO } & \multirow[b]{2}{*}{ Parameter } & \multirow[b]{2}{*}{ Satuan } & \multicolumn{4}{|c|}{ Kualitas Produk Kompos } & \multirow{2}{*}{$\begin{array}{c}\text { Permentan } \\
28 \text { Th } \\
2009\end{array}$} & \multirow{2}{*}{$\begin{array}{c}\text { SNI } \\
\text { Kompos }\end{array}$} \\
\hline & & & Rawajati & Puspiptek & $\begin{array}{c}\text { Kuala } \\
\text { Kencana }\end{array}$ & $\begin{array}{l}\text { Temba } \\
\text { gapura }\end{array}$ & & \\
\hline 1 & C-Organik & $\%$ & 9,33 & 11,62 & 12,25 & 8,61 & $>12$ & $9,8-32$ \\
\hline 2 & $\mathrm{C} / \mathrm{N}$ rasio & & 13 & 11 & 18 & 17 & $15-25$ & $10-20$ \\
\hline 3 & Kadar air & $\%$ & 73,76 & 63,10 & 70,30 & 45,89 & $15-25$ & $<50$ \\
\hline \multirow[t]{5}{*}{4} & \multicolumn{8}{|l|}{ Logam berat } \\
\hline & AS & Ppm & $\mathrm{td}$ & $\mathrm{Td}$ & $\mathrm{Td}$ & $\mathrm{td}$ & $<10$ & $<13$ \\
\hline & $\mathrm{Hg}$ & Ppm & 0,04 & $\mathrm{Td}$ & 0,06 & 0,01 & $<1$ & $<0,8$ \\
\hline & $\mathrm{Pb}$ & Ppm & 10 & 11 & 3 & 8 & $<50$ & $<150$ \\
\hline & $\mathrm{Cd}$ & Ppm & 0,2 & 0,0 & 0,2 & 0,1 & $<10$ & $<3$ \\
\hline 5 & $\mathrm{pH}$ & & 7,4 & 5,8 & 7,4 & 6,9 & $4-8$ & 6,8-7,49 \\
\hline \multirow[t]{7}{*}{6} & \multicolumn{8}{|l|}{ Kadar total } \\
\hline & N Organik & $\%$ & 0,55 & 0,78 & 0,55 & 0,37 & & \\
\hline & $\mathrm{N}-\mathrm{NH} 4$ & $\%$ & 0,07 & 0,09 & 0,07 & 0,07 & & \\
\hline & $\mathrm{N}-\mathrm{NO} 3$ & $\%$ & 0,09 & 0,20 & 0,08 & 0,08 & & \\
\hline & $\mathrm{N}$-total & $\%$ & 0,71 & 1,08 & 0,70 & 0,51 & $<6$ & $>0,4$ \\
\hline & P205 & $\%$ & 0,17 & 0,12 & 0,16 & 0,19 & $<6$ & $>0,1$ \\
\hline & K20 & $\%$ & 0,34 & 0,25 & 0,44 & 0,42 & $<6$ & $>0,2$ \\
\hline \multirow[t]{3}{*}{7} & \multicolumn{8}{|c|}{ Mikroba kontaminan } \\
\hline & E. coli & Cfu/g;cfu/ml & negatif & negatif & negatif & negatif & $<102$ & $<103$ \\
\hline & Salmonella sp & Cfu/g;cfu/ml & negatif & negatif & negatif & negatif & $<102$ & $<12$ \\
\hline \multirow[t]{8}{*}{8} & \multicolumn{8}{|c|}{ Kadar unsur mikro } \\
\hline & $\mathrm{Fe}$ & Ppm & 3820 & 8316 & 2143 & 20817 & $0-8000$ & $<20.000$ \\
\hline & $\mathrm{Mn}$ & Ppm & 250 & 1290 & 191 & 1224 & $0-5000$ & $<1.000$ \\
\hline & $\mathrm{Cu}$ & Ppm & 6 & 9 & 13 & 25 & $0-5000$ & $<100$ \\
\hline & $\mathrm{Zn}$ & Ppm & 46 & 42 & 82 & 61 & $0-5000$ & $<500$ \\
\hline & $\mathrm{B}$ & Ppm & 3 & 5 & 2 & 8 & $0-2500$ & \\
\hline & Co & Ppm & 3 & 6 & 1 & 11 & $0-20$ & 34 \\
\hline & Mo & $\mathrm{Ppm}$ & 4 & $\mathrm{Td}$ & $\mathrm{Td}$ & 4 & $0-10$ & \\
\hline
\end{tabular}

Catatan : Analisa dilakukan di Laboratorium Balai Penelitian Tanah - Bogor. 


\subsection{Keberadaan Mikroba Kontaminan}

Yang dimaksud dengan mikroba kontaminan menurut SNI Kompos dan Permentan No. 28 Tahun 2009 adalah E. coli dan Salmonella sp. ${ }^{14 \text { dan } 15)}$. Kedua jenis mikroba tersebut termasuk jenis mikroba yang patogen, dan keberadaannya dijadikan sebagai parameter adanya bakteri patogen yang lain di dalam kompos yang dihasilkan. Bakteri E.coli dan Salmonella sp. biasanya hidup di dalam saluran pencernaan manusia ataupun hewan, dan bersifat patogen bila berada di luar usus. Oleh karena itu, kompos yang dibuat dari bahan baku yang berasal dari kotoran ternak atau bahan baku yang terkontaminasi dengan kotoran ternak atau telah mengalami proses pembusukan, memiliki potensi yang besar untuk terpapar dengan E. coli dan Salmonella sp.

Hasil penelitian menunjukkan bahwa produk kompos yang berasal dari keseluruhan lokasi penelitian dinyatakan tidak mengandung bakteri E. coli dan Salmonella sp. Artinya, produk komposnya higienis dan bebas dari bakteri patogen. Hasil ini sangat positif, karena komposter kapasitas 60 liter yang digunakan, sangat kecil kemungkinannya untuk mampu membunuh bakteri patogen, karena efek pembentukan panas dari proses pengomposannya tidak tinggi. Dengan menggunakan komposter sejenis yang volumenya lebih besar (160 liter), suhu tertinggi yang pernah dilaporkan hanya 50 $55{ }^{\circ} \mathrm{C}$ dan berlangsung selama 10 hari ${ }^{5}$. Suhu yang dibutuhkan untuk mematikan bakteri patogen, lebih tinggi dari $55^{\circ} \mathrm{C}$ atau $65^{\circ} \mathrm{C}^{9}$. Sebagai perbandingan, suhu yang ditimbulkan oleh proses pengomposan sampah kota sistem open windrow dengan volume bahan baku yang besar (lebih besar dari $6 \mathrm{~m}^{3}$ ), dan dianggap dapat mematikan bakteri patogen adalah $60-75^{\circ} \mathrm{C}$, dan terjadi untuk rentang waktu minimal 5 (lima) minggu 11-13).

Bebasnya bakteri patogen dari produk komposnya, tidak terlepas dari tatacara proses pembuatan kompos yang baik, yang dimulai dari seleksi yang ketat terhadap bahan baku yang digunakan. Bahan baku yang digunakan merupakan sampah dapur yang masih segar (belum mengalami proses pembusukan), yang kadang-kadang dicampur dengan sampah halaman berupa daun-daunan. Proses pemilihan bahan baku yang ketat memang harus dilakukan, untuk menghindarkan dari kontaminasi bakteri patogen. Sekali bahan bakunya tercemar bakteri patogen, maka bakteri tersebut kemungkinan besar akan tetap berada di produk komposnya, karena proses pengomposan dengan komposter bervolume kecil, tidak memiliki kemampuan untuk mematikan bakteri patogen yang sudah terlanjur ada.

Produk kompos yang pembuatannya dilakukan secara benar, dan melibatkan volume bahan baku yang besar, hampir tidak pernah dilaporkan tercemar dengan E. coli dan Salmonella sp. karena akan mati oleh proses insulasi suhu yang tinggi $i^{6-10}$ )

\subsection{Tingkat Kematangan}

Ada beberapa parameter yang dapat digunakan untuk menilai tingkat kematangan kompos. Masing-masing parameter sebaiknya tidak digunakan secara mutlak (sendiri) ${ }^{9}$, melainkan dengan dikombinasikan dengan parameter yang lain. Salah satu parameter untuk menilai tingkat kematangan kompos adalah rasio $\mathrm{C} / \mathrm{N}^{6-10)}$. Karbon diperlukan oleh mikroba sebagai sumber energi dalam proses untuk mendekomposisi bahan organik. Sedangkan Nitrogen dibutuhkan mikroba sebagai sumber makanan untuk pembentukan sel-sel tubuhnya. Kedua unsur tersebut dibutuhkan dalam jumlah besar dalam komposisi keseimbangan yang tertentu. Untuk proses pengomposan yang baik, sarat rasio $\mathrm{C} / \mathrm{N}$ bahan baku adalah 30 , dan kompos dikatakan matang apabila rasio $\mathrm{C} / \mathrm{N}$ nya turun menjadi lebih kecil dari 20 6-10). Penggunaan rasio $\mathrm{C} / \mathrm{N}$ untuk mengukur 
tingkat kematangan kompos menjadi valid apabila rasio awal dari bahan baku yang digunakan adalah 20-409), seperti umumnya rasio $\mathrm{C} / \mathrm{N}$ sampah organik yaitu $37,1^{5}$ ).

Hasil analisa rasio $\mathrm{C} / \mathrm{N}$ kompos dari ke empat lokasi seperti terlihat pada Tabel 1 , sudah lebih kecil dari 20 , sehingga menggambarkan produk kompos yang sudah memenuhi kriteria kompos matang berdasarkan rasio $\mathrm{C} / \mathrm{N}$. Adanya nilai rasio $\mathrm{C} / \mathrm{N}$ yang berbeda pada masing-masing lokasi, menggambarkan perbedaan tingkat kematangan, karena pada akhirnya rasio $\mathrm{C} / \mathrm{N}$ akan mendekati rasio $\mathrm{C} / \mathrm{N}$ tanah yaitu 12.

Perbandingan nilai antara $\mathrm{N}-\mathrm{NH}_{4}$ dan N-total, dapat juga dijadikan untuk mengevaluasi nilai kematangan ${ }^{9}$. Kompos dikatakan matang apabila nilai $\mathrm{N}-\mathrm{NH}_{4}$ lebih kecil dari $10 \% \mathrm{~N}$-total. Hasil penelitian pada Tabel 1, sudah menunjukkan nilai yang memenuhi kriteria kematangan, kecuali produk kompos yang berasal dari Tembagapura.

Begitu juga dengan perbandingan nilai $\mathrm{N}-\mathrm{NO}_{3}$ dan $\mathrm{N}-\mathrm{NH}_{4}$ dapat digunakan untuk menilai tingkat kematangan kompos 9 dan 20). Kompos dikatakan matang apabila rasio $\mathrm{N}-\mathrm{NO}_{3} / \mathrm{N}-\mathrm{NH}_{4}>1{ }^{20)}$. Hasil penelitian rentang rasio $\mathrm{N}-\mathrm{NO}_{3} / \mathrm{N}-\mathrm{NH}_{4}$ kompos yang diteliti sebesar 1,1-2,2, telah menggambarkan kematangan semua kompos yang diteliti.

Parameter lain yang dapat digunakan untuk menilai kematangan adalah tingkat kehancuran, warna dan bau dari produk kompos yang dihasilkan ${ }^{6-10)}$. Semua produk kompos yang dihasilkan sudah terdekomposisi sempurna, sehingga bentuknya sudah hancur atau halus, berwarna coklat kehitaman dan berbau seperti tanah. Kondisi tersebut menggambarkan kematangan kompos

Berdasarkan pembahasan semua parameter tesebuat di atas, dapat disimpulkan bahwa produk kompos yang dihasilkan dari ke empat lokasi sudah memenuhi kriteria kompos matang.

\subsection{Kesesuaian Dengan Permentan Pupuk Organik dan SNI Kompos}

Secara umum dapat dikatakan bahwa semua kompos yang diteliti sudah memenuhi persaratan Permentan Pupuk Organik atau SNI Kompos, walaupun ada beberapa parameter yang lebih tinggi, sehingga perlu mendapatkan pembahasan yang lebih mendalam.

Kandungan C-organik kompos yang berada pada rentang $8,61 \%$ sampai 12,25 $\%$, memperlihatkan adanya produk kompos yang tidak memenuhi Permentan 28 yaitu $>12 \%$, atau SNI kompos yang membatasi batas bawahnya pada 9,8\%. Data tersebut memberikan gambaran adanya produk kompos yang kurang kandungan C-organiknnya, namun tidak selalu berarti identik dengan kualitas kompos yang rendah. Proses pengomposan merupakan proses penguraian $\mathrm{C}$-organik yang terus berlangsung sampai terbentuk kestabilan Karbon. Besarnya persentase nilai kestabilan C-organik sangat ditentukan oleh nilai persentase besaran C-organik pada bahan baku awal, serta rasio $\mathrm{C} / \mathrm{N}$ kompos yang dihasilkan. Adanya batas bawah kandungan C-organik, karena C organik merupakan unsur penting bagi pupuk organik dalam rangka untuk meningkatkan kandungan C-organik tanah yang pada umumnya sudah rendah sampai sangat rendah yaitu di bawah $2 \%{ }^{16)}$.

Kadar air yang dipersyaratkan oleh Permentan 28 sebesar $15-25 \%$, sedangkan yang dipersyaratkan SNI sebesar $50 \%$ (maksimum) atau yang umumnya disarankan oleh para ahli sebesar 35-45\% 6-10). Kalau dianalisis, maka angka kadar air yang ditentukan oleh Permentan 28, merupakan angka yang terlalu rendah untuk kadar air kompos. Angka yang ideal adalah angka yang banyak dikemukakan para ahli, yaitu $35-45 \%$. Kadar air kompos penelitian sebesar 45,89-73,76\% memberikan gambaran kadar air yang masih terlalu tinggi, terutama apabila kompos tersebut 
akan dikemas. Tingginya kadar air tersebut disebabkan oleh penggunaan sampah dapur yang memang berkarakter basah. Kondisi demikian harus mendapatkan perhatian, karena akan menghambat proses pengomposan. Cara mengatasinya adalah dengan menambahkan bahan organik berkarakter kering (daun kering, serbuk gergaji) pada saat proses pengomposan berlangsung, dan mengangin-anginkan terlebih dahulu kompos yang telah matang.

Kandungan logam berat dari kompos yang diteliti memenuhi persyaratan Permentan 28 ataupun SNI kompos. Dengan demikian tidak perlu ada keraguan untuk menggunakan produk komposnya karena khawatir terkontaminasi logam berat.

Tingkat keasaman $(\mathrm{pH})$ merupakan parameter yang perlu pula untuk diperhatikan, karena pada awal proses pengomposan akan terjadi penurunan $\mathrm{pH}$ sebagai akibat penguraian bahan organik menjadi asamasam organik ${ }^{6-10)}$. Setelah itu $\mathrm{pH}$ terus naik menjadi netral sampai cenderung basa. Kalau pH suatu produk pupuk kompos asam, berarti kompos tersebut ada kecenderungan belum matang dan berbahaya bagi tanaman, terutama untuk pembibitan tanaman. Standar $\mathrm{pH}$ menurut Permentan 28 sebesar 4-8, sebenarnya kalau dicermati, nilai batas bawahnya terlalu rendah. Sebagai perbandingan nilai $\mathrm{pH}$ menurut SNI adalah $6,8-7,49$. Kompos hasil penelitian memiliki rentang $\mathrm{pH}$ 5,8-7,4, memberikan nilai $\mathrm{pH}$ yang cukup baik, kecuali kompos yang berasal dari Perumahan Puspiptek..

Standar Permentan 28, membatasi kandungan unsur pupuk ( $\mathrm{N}$ total, $\mathrm{P}_{2} \mathrm{O}_{5}$ dan $\mathrm{K}_{2} \mathrm{O}$ ) pada batas atas (lebih kecil dari $6 \%$ ), sedangkan SNI membatasi pada batas bawah. Hasil penelitian menunjukkan bahwa nilai $\mathrm{N}$ total, $\mathrm{P}_{2} \mathrm{O}_{5}$ dan $\mathrm{K}_{2} \mathrm{O}$ dari kompos yang diteliti lebih kecil dari batas atas standar Permentan 28 dan lebih tinggi dari batas bawah SNI kompos, sehingga dapat dikatakan berkualitas baik.

Unsur mikro merupakan zat yang dibutuhkan tanaman dalam jumlah sedikit dan tidak boleh berlebihan. Kandungan unsur mikro dari kompos yang diteliti secara umum memenuhi standar Permentan atau SNI Kompos, kecuali Fe dari lokasi Tembagapura. Nilai Fe tersebut, perlu diteliti lebih lanjut apakah ada kesalahan dalam analisa atau ada kaitannya dengan lokasi Tembagapura yang merupakan wilayah tambang tembaga. Untuk unsur mikro Mn pada kompos yang diteliti ada yang tidak memenuhi SNI kompos, tetapi masih memenuhi standar Permentan 28.

\section{KESIMPULAN DAN SARAN}

\subsection{Kesimpulan}

Berdasarkan hasil penelitian dan pembahasan, dapat ditarik beberapa kesimpulan sebagai berikut:

1. Upaya pembuatan kompos sampah rumah tangga dengan menggunakan "komposter", dapat membantu upaya pengelolaan sampah kota dalam bentuk: mengurangi jumlah timbulan sampah di sumber, mengurangi biaya transportasi pengangkutan sampah dan dapat memperpanjang umur TPA.

2. Proses pengomposan menggunakan "komposter" aerobik dapat berjalan dengan baik dan cukup efektif, serta menggambarkan proses dekomposisi secara aerobik.

3. Produk kompos yang dihasilkan merupakan kompos yang berkualitas baik karena: bebas dari mikroba kontaminan (patogen), memenuhi persyaratan kompos matang dan secara umum memenuhi parameter-parameter yang dipersyaratkan oleh Permentan No. 28 Tahun 2009 atau SNI kompos Tahun 2004.

\subsection{Saran}

Berdasarkan hasil penelitian dan kesimpulan, disarankan:

1. Untuk mendapatkan produk kompos yang bebas mikroba kontaminan maka 
seleksi bahan baku perlu mendapatkan perhatian, yaitu tidak menggunakan kotoran hewan yang masih segar dan bahan organik yang telah membusuk.

2. Untuk mengkondisikan kadar air yang optimal, maka perlu menambahkan bahan-bahan organik yang memiliki karakter kering seperti daun kering, serbuk gergaji, kompos matang dan lain-lain.

\section{DAFTAR PUSTAKA}

1. Kementerian Negara Lingkungan Hidup, 2008. Undang-Undang Republik Indonesia Nomor 18 Tahun 2008 Tentang Pengelolaan Sampah

2. Dinas Kebersihan DKI Jakarta, 2005. Solid Waste Management for DKI Jakarta, Master Plan Review and Program Development.

3. Badan Pusat Statistik, 2011. Penduduk Indonesia 2010.

4. Kementerian Negara Lingkungan Hidup, 2008. Statistik Persampahan Indonesia Tahun 2008.

5. Sahwan, F.L., R. Irawati dan F. Suryanto, 2004. Efektivitas Pengkomposan Sampah Kota dengan Menggunakan "Komposter" Skala Rumah Tangga. Jurnal Teknologi Lingkungan, Pusat Teknologi LingkunganBPPT, 5(2): 134-139.

6. Golueke, C.G., 1977. Biological Processing: Composting and Hydrolysis; In Handbook of Solid Waste Management. Van Nostrand Reinhold Company, New York.

7. Haug, R.T., 1980. Compost Engineering, Principles and Practice, An Arbor Science Publisher Inc., Michigan.

8. Tchobanouglous, G., H. Theisen and S. Vigil, 1993. Integrated Solid Waste Management, Engineering Principles and Management Issues, Mc Graw-Hill Inc., USA.

9. Epstein, E., 1997. The Science of Composting. Technomic Publishing Company Inc., USA.

10. Wahyono, S., F.L. Sahwan dan F.
Suryanto, 2003. Menyulap Sampah Menjadi Kompos. Pusat Pengkajian dan Penerapan Teknologi Lingkungan BPPT, Jakarta.

11. Sahwan, F.L., 1999. Karakteristik Kompos dari Sampah Kota di Plant Pengkomposan Tambakboyo, Kabupaten Dati II Sleman, Yogyakarta. Jurnal Sains dan Teknologi Indonesia, BPPT, Volume 1 Nomor 4.

12. Sahwan, F.L., 2010. Kualitas Produk Kompos dan Karakteristik Proses Pengomposan Sampah Kota Tanpa Pemilahan Awal. Jurnal Teknologi Lingkungan, Pusat Teknologi Lingkungan-BPPT, 11 (1): 79-85.

13. Sahwan, F.L., S. Wahyono dan F. Suryanto, 2010. Kualitas dan Produksi Pupuk Organik Granul (POG) Sampah Kota serta Manfaatnya untuk Mengurangi Pengaruh Emisi Gas Rumah Kaca. Jurnal Teknologi Lingkungan, Pusat Teknologi Lingkungan-BPPT, Edisi Khusus Global Warming.

14. Badan Standardisasi Nasional, 2004. Standar Nasional Indonesia, SNI 197030-2004 Tentang Spesifikasi Kompos dari Sampah Organik Domestik.

15. Menteri Pertanian Republik Indonesia, 2009. Peraturan Menteri Pertanian No 28/Permentan/SR.130/5/2009, Tentang Pupuk Organik, Pupuk Hayati dan Pembenah Tanah. Berita Negara Republik Indonesia Tahun 2009 Nomor 137.

16. Kementerian Pertanian Republik Indonesia, 2010. Pemulihan Kesuburan Tanah pada Lahan Sawah Berkelanjutan. Badan Litbang Pertanian dan Ditjen Tanaman Pangan.

17. Hogg, D., J. Bart, E. Favoino, M. Centemero, V. Caimi, F. Amlinger, W. Devliegher, W. Brinton and S. Antler, 2002. Review of Compost Standards in Belgium (Flanders). Nation Specific Supplement 2, The Waste and Resources Action Programme (WRAP). 